Marine ecology

\section{Vent communities in Atlantic too}

\author{
from Eve C. Southward
}

SURPRISE and great interest have been aroused by the discovery of hydrothermal vent communities, predominantly dense colonies of huge clams and red-plumed tube worms surrounding hot sulphide-rich springs in the ocean floor'. They stand out like oases on the otherwise sparsely populated sea bed, their members exploit chemosynthesis as a source of food and include many species new to science. More recently 'vent-type' communities have also been found at cold seeps ${ }^{2-4}$. Hot-vent communities have been reported only from the eastern Pacific, but the cold-vent type are more widely spread throughout the Pacific. Kenicutt et al..$^{5}$ in a recent issue of Nature and Paull et al. ${ }^{6}$ on page 709 of this issue now report the first cold-vent communities to be found in the Atlantic.

Photosynthesis by phytoplankton is the origin of the organic compounds that are the basis of the food chain for marine life but, at 2,000 $\mathrm{m}$ depth, fall-out from surface production is small and there is no light to support photosynthesis. At such depths, hydrothermal vents expel hot, sulphiderich water into cold oxygen-containing ocean bottom water; the resultant mix is ideal for sulphur-oxidizing chemoautotrophic bacteria, which can grow both in suspension in the water and on surfaces around the vents'. Some also live symbiotically in the tissues of the largest animals in the vent communities and are important in providing them with nutrition, just as the unicellular plants that live in tissues of giant clams and other animals on coral reefs supply their hosts with products of photosynthesis.

Vent fluids contain hydrogen sulphide, other reduced inorganic compounds and methane, as well as high concentrations of metals in solution, all derived during the passage of seawater through very hot rocks under enormous pressure'. Hence the chemical energy for carbon fixation by chemoautotrophs is considered to be 'new', as it is unconnected with seasurface production; this contrasts with normal biogenic sulphide produced by sulphate reduction in sediments, which is the result of bacterial degradation of organic matter originating from photosynthesis.

At cold seeps, fluid is seawater or brine rich in sulphide and sometimes hydrocarbons. Both hot and cold-vent communities are characterized by dense populations of two types of bivalve mollusc (families Vesicomyidae and Mytilidae) and the curious vestimentiferan tube worms (phylum Pogonophora) which have no mouth or gut yet can grow up to 2 metres long and 30 millimetres wide. Although various other animal groups occur at vents, diversity is low and these three can be called indicators. All three contain symbiotic bacteria.

Communities associated with hot or warm vents have been found in the East Pacific Rise, Galapagos Rift region and Juan de Fuca Ridge, and also in the Guaymas Basin (Gulf of California)? all in the eastern Pacific. Communities associated with cold seeps have a wider geographical spread. The first were found off California, near San Diego; they contain only vestimentiferans. Sulphide was not detected in the water. Other cool

Comparison of ${ }^{13} \mathrm{C}$ depletion indicated by $\delta^{13} \mathrm{C}$ in the flesh of animals from the two new sites $-600 \mathrm{~m}$ : Louisiana; $3,266 \mathrm{~m}$ : Florida.

$\begin{array}{lcc} & 600 \text { metres } & 3,266 \text { metres } \\ \text { Vestimentifera } & -27 \% & -42.4 \% \\ \text { Bivalve mollusc } & -35.5 \% & -74.3 \% \\ & \text { (Calyptogena) } & \text { (mytilid) }\end{array}$

seeps are close to the hot-vent region in the Guaymas Basin?, off Oregon ${ }^{3}$ and in the Japan Trench, Tenryu Canyon and Sagami Bay ${ }^{4}$, on the western margin of the Pacific.

Although hydrothermal areas are known on the Mid-Atlantic Ridge, no hotvent communities have been found in the Atlantic Ocean. A single large vestimentiferan was trawled at a depth of 500 metres off the coast of Surinam ${ }^{8}$, but the two seep sites in the Gulf of Mexico described by Kennicutt et al. ${ }^{5}$ and Paull et al. ${ }^{\circ}$ are the first on the eastern margin of North America at which the typical venttype community has been found.

The two Atlantic sites are at very different depths. The first, at 600 metres off Louisiana, has obviously oily sediments

\section{0 years ago}

\section{THE RECENT TOTAL ECLIPSE OF THE SUN}

I OBSERVED the eclipse from Tahoraite. I determined to concentrate my whole attention on the corona, and the corona alone. The moment "totality" occurred I turned my gaze towards the sun, and having previously, to save time, drawn disks on several pages of my pocketbook, I hurriedly took sketch after sketch of the shape of the corona, the rays of which were much better marked than I had been led to expect. My object in taking several sketches was to record any change in the position of the rays. I took five during the short time of totality, and their agreement is so clear as regards the number and relative position and length of the main rays, that it fully confirms the general impression left on my mind as to the fixity of this phenomenon. I was just engaged in making a last estimate of the extent of the corona between $35^{\circ}$ and $90^{\circ}$, when a cry arose from the bystanders, "Look at the red flame shooting out to the left!" I withstood the temptation, and and was found by trawling after the collection of oil-stained cores. Its fauna includes two vesicomyid clam species and a vestimentiferan, but apparently no vent mytilids. The second, in $3.266 \mathrm{~m}$ at the foot of the Florida Escarpment, was discovered by the manned submersible Alvin; mytilids, vesicomyids and vestimentiferans were all collected ${ }^{2}$.

Comparing data on ${ }^{13} \mathrm{C}^{12} \mathrm{C}$ ratios from these two sites ${ }^{5.6}$ shows that there is much greater depletion of ${ }^{13} \mathrm{C}$ in animals from the deep site (see table). The figure for the mytilid from the deep site is exceptional for an animal, the lowest previous measurment being $-45.9 \%$ in a symbiontcontaining pogonophore not associated with a vent ${ }^{4}$. The $\delta^{13} \mathrm{C}$ for an animal's tissue is normally close to that of its food, a little fractionation taking place during digestion and assimilation. Greater fractionation, resulting in depletion of ${ }^{1.3} \mathrm{C}$, occurs during photosynthetic or chemosynthetic fixation of carbon from carbon dioxide, the depletion being around $20 \%$ and the final value for $\delta^{13} \mathrm{C}$ depending on the original value for the carbon dioxide used. When considering possible sources of carbon for animals at vents, it is important to obtain $\delta^{13} \mathrm{C}$ values for all the likely sources. This very useful technique is also helping in the measurement of the contribution made by chemoautotrophic symbionts to the nutrition of non-vent animals living in reducing sediments in shallow water ${ }^{10}$.

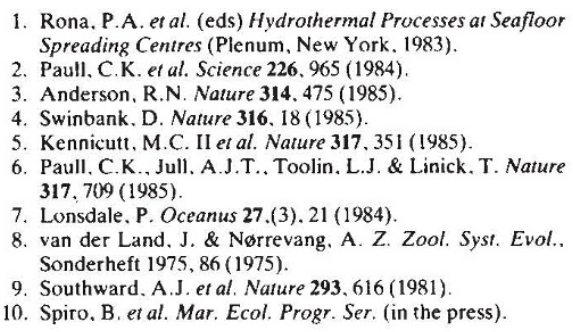

Eve C. Southward is at the Marine Biological Laboratory, Plymouth PL1 2PB, UK.

observed the almost sudden disappearance of the corona on the reappearance of the sun.

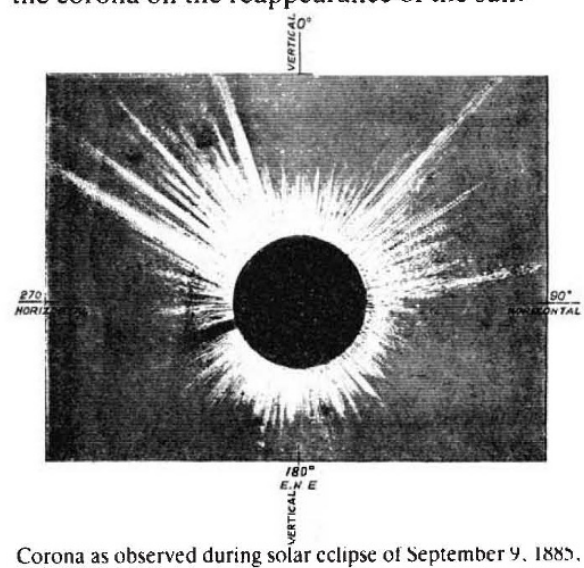

Corona as observed during solar cclipse of September $y$. I $18 \times$ as seen from Tahoraite. North Island, New Zealand. about 40 miles north of centre line of totality. (N.B - Corona alone was observed: relative position and lengths of rays reliable: absolute lengths to be taken with caution.)

from Nature 32 631, 29 October 1885. 